\title{
UPAYA MENINGKATAN KESEHATAN MASYARAKAT DAN SOSIALISASI SUMBER BAHAN PANGAN MENYEHATKAN (TEPUNG CANNALINA)
}

\author{
Nita Noriko ${ }^{1}$, Elma Alfiah ${ }^{2 *}$ \\ ${ }^{1}$ Bioteknologi, Fakultas Sains dan Teknologi, Komplek Masjid Agung Al Azhar \\ Jl. Sisingamangaraja, Kebayoran Baru Jakarta Selatan 12110 \\ ${ }^{2}$ Gizi, Fakultas Sains dan Teknologi, Komplek Masjid Agung Al Azhar \\ Jl. Sisingamangaraja, Kebayoran Baru Jakarta Selatan 12110 \\ Email Penulis Korespondensi: elma.alfiah@uai.ac.id
}

\begin{abstract}
Abstrak
Dusun Teluk Bunder desa Dewisari, Rengasdengklok, Karawang, Jawa Barat terletak di DAS Citarum yang masyarakatnya sudah terpapar pola makan masyarakat perkotaan yang cenderung mengkonsumsi garam, gula, lemak, tinggi, serta rendah serat dan protein. Jika tidak ada upaya perbaikan perspektif tentang pola makan yang baik di masyarakat maka akan memicu timbulnya penyakit hipertensi dan diabetes mellitus tipe 2 (T2DM). Komplikasi yang dapat timbul dari kedua penyakit tersebut adalah berbagai keluhan cardiac, stroke, glaucoma, neuropathy dan stroke. Kondisi ini dapat menurunkan kualitas dan produktifitas SDM. Upaya untuk memperbaiki pola makan masyarakat dalam bentuk monitoring status kesehatan dengan parameter tekanan darah, gula darah, asam urat, kolesterol, dan berat badan serta edukasi pola makan sehat kepada masyarakat diperlukan. Tujuan pengabdian masyarakat adalah untuk meningkatkan status kesehatan masyarakat. Metode pelaksanaan yang dilakukan adalah monitoring status kesehatan masyarakat, pemberian edukasi mengenai pola makan sehat, jenis makanan yang menyehatkan seperti yang berasal dari tepung komposit ganyong spirulina atau (Tepung Cannalina) dan evaluasi hasil edukasi. Kondisi kesehatan para ibu rumah tangga menunjukkan banyaknya kelainan metabolik seperti gula darah, kolesterol dan asam urat di atas normal serta gemuk dan obesitas.
\end{abstract}

Kata kunci : Cannalina, Hipertensi, Pola makan, Teluk bunder, T2DM

\begin{abstract}
Teluk Bunder, Dewisari Village, Rengasdengklok, Karawang, West Java is located in the Citarum watershed where the community ha been exposed to the eating patterns of urban communities who tend to consume salt, sugar, fat, high, and low in fiber and protein. If there is no effort to improve perspective on eating patterns in the community it will trigger the onset of hypertension and type 2 diabetes mellitus. Complications that can arise from the two diseases are various cardiac diseases, stroke, glaucoma, neuropathy and, stroke. This condition can reduce the quality and productivity of human resources. Efforts to improve community eating patterns in the form of monitoring health status with parameters of blood pressure, blood sugar, uric acid, cholesterol, and body weight and education on healthy eating patterns to the community are needed. Community services aimed to improve the health status of the community. The method of implementation carried out was monitoring public health status, providing education about healthy eating patterns, types of healthy foods such as canna spirulina flour or (Cannalina Flour) and evaluation of educational results. The health conditions of housewives showed some metabolic abnormalities such as blood sugar, cholesterol and uric acid above normal as well as fat and obesity.
\end{abstract}

Keywords: Cannalina, Hypertension, Diet, Bunder bay, T2DM 


\section{PENDAhUluan}

Sungai Citarum terletak di Jawa Barat dengan luas Daerah Aliran Sungai (DAS) sekitar $12.000 \mathrm{~km}$ persegi. Kabupaten yang dilewati sungai Citarum mencakup kabupaten Bandung, Purwakarta, Subang, Sumedang, Bekasi, Cianjur, Bogor, Indramayu dengan panjang 315 $\mathrm{km}$ dan bermuara ke Laut Jawa. Jumlah kecamatan yang terletak pada DAS Citarum adalah 118 salah satunya adalah Rengasdengklok di Kabupaten Karawang dengan luas $31,51 \mathrm{~km}^{2}$ adalah salah satu kecamatan yang terdapat yang berjarak $79 \mathrm{~km}$ dari DKI Jakarta. Rengasdengklok terdiri atas 9 desa diantaranya desa Dewisari yang memiliki 4 dusun dengan kepadatan penduduk di wilayah ini adalah sebesar $31.681,20$ penduduk per $\mathrm{km}^{2}$. Pada 2014 hingga 2017, hampir seluruh desa di kecamatan Rengasdengklok ini mengalami peningkatan jumlah penduduk, yaitu berkisar antara 0,05 - 3,52\% pertahun (Badan Pusat Statistik Kabupaten Karawang, 2018). Salah satu dusun adalah Teluk Bunder dengan total penduduk 1999 orang (682 kepala keluarga). Tingkat pendidikan dusun Teluk Bunder 50\% adalah lulusan SMP. Profesi yang digeluti adalah petani merangkap buruh dengan penghasilan harian tiap kepala keluarga sekitar Rp 50.000. Sosial ekonomi di bawah UMR mempengaruhi pola makan, seperti yang disampaikan oleh Bidan di dusun sebagai narasumber Miatul Khumro yang mengatakan bahwa masyarakat umumnya mengkonsumsi makanan dari ikan asin, telur dan ayam goreng (fast food) tidak bermerek. Balita dan anak-anak menyukai makanan kemasan seperti chiki.

Hal ini juga terjadi di salah satu RT Lampiri Pondok Kelapa Jakarta Timur dengan kondisi sosial masyarakat berpenghasilan dibawah UMR 2017 (Rp 3.355.750). Pendidikan umumnya lulusan SMP dengan profesi masyarakat di Lampiri adalah buruh cuci, pedagang makanan gerobak, supir ojek. Konsumsi harian masyarakat adalah ikan asin, ayam goreng fast food. Dampak dari pola konsumsi seperti yang digambarkan adalah tekanan darah sistol rata-rata masyarakat usia 30 sampai 50 tahun $140 \mathrm{mmHg}$. Kondisi ini juga terjadi di suatu majlis taklim Cilandak. Prevalensi hipertensi pada ibu-ibu mencapai $41,7 \%$ dengan usia di atas 40 tahun dengan kondisi sosial dan tingkat ekonomi yang rendah, tidak bekerja, penghasilan di bawah UMR. Angka tersebut di atas rata-rata di Jakarta yaitu
28,6\%. Faktor yang mendukung timbulnya hipertensi adalah makanan asin, minuman berkafein dan bumbu penyedap (Fitriani, 2012).

Berdasarkan data Riskesdakes, hipertensi merupakan penyakit peringkat pertama penyakit tidak menular yang ditemukan di fasilitas kesehatan di semester pertama 2018 yaitu $25,8 \%$ penduduk Indonesia dan meningkat pada 2016 menjadi $32,4 \%$. Hipertensi mempunyai kaitan dengan T2DM yang disebabkan kurangnya konsumsi serat. Pola makan dengan diet makanan berserat 11,5 gram/hari dapat menurunkan tekanan sistol $1,13 \mathrm{mmHg}$ dan diastole 1,26 mg Hg (Streppel et al, 2005, Sun et all, 2018). mengemukakan bahwa konsumsi serat sereal, sayur dan buah-buahan mempunyai pengaruh menurunkan hipertensi 4 kali di Amerika pada kasus 18.433 kasus hipertensi berusia 18 tahun ke atas. Komplikasi yang terjadi adalah stroke, jantung dan gagal ginjal. Hasil pengabdian masyarakat terhadap 29 juta kasus diabetes mellitus dan 86 juta prediabetes pada 2014 (Staruschenko, 2017). Penyakit ini secara ekonomi membebani ekonomi masyarakat dan negara. Oleh sebab itu diperlukan upaya untuk memproteksi masyarakat dari ke dua penyakit tidak menular yang dihadapi Indonesia.

Jumlah penduduk kecamatan Rengasdengklok adalah 103.430 orang dengan fasilitas kesehatan yang tercatat hanyalah satu rumah sakit dan dua Puskesmas. Jumlah fasilitas kesehatan yang ada dirasa belum cukup untuk melayani masyarakat terutama tentang upaya proteksi terhadap penyakit hipertensi, T2DM serta pola makan sehat. Hal ini dibuktikan dengan kondisi masyarakat yang belum memahami pola makan sehat. Setiap hari masyarakat mengkonsumsi makanan dari ikan asin, telur dan makanan fast food. Selain itu upaya proteksi untuk mengontrol kesehatan seperti tekanan darah, gula darah, kolesterol, asam urat dan berat badan serta edukasi akan pola makan berdasarkan wawancara merupakan hal yang dibutuhkan masyarakat di dusun Teluk Bunder Rengasdengklok.

Rekomendasi solusi permasalahan terhadap kedua penyakit tersebut menurut Prof. Tjandra (Kementerian Kesehatan, 2018) adalah:

a. Mengembangkan dan memperkuat kegiatan deteksi dini hipertensi dan T2DM secara aktif (skrining)

b. Meningkatkan akses masyarakat terhadap pelayanan dini melalui kegiatan posbindu 
c. Meningkatkan akses penderita terhadap pengobatan hipertensi melalui revitalisasi puskesmas

d. Meningkatkan kesadaran masyarakat dan perubahan pola hidup kearah yang lebih sehat dengan cara promosi kesehatan seperti mengkonsumsi cukup sayur buah, rendah garam dan lemak, rajin melakukan aktifitas dan tidak merokok

Berdasarkan solusi tersebut, yang dapat disumbangkan kepada masyarakat adalah pemeriksaan tekanan darah, gula darah, kolesterol asam urat, berat badan serta edukasi agar masyarakat mengetahui pola makanan sehat, sumber makanan berserat dengan Indeks glikemik rendah dan sedang. Masyarakat dalam pengabdian masyarakat ini adalah para ibu rumah tangga di desa Dewi Sari.

\section{METODE PELAKSANAAN}

Kegiatan pengabdian masyarakat ini diawali dengan pemberian penyuluhan terkait penyakit tidak menular (PTM) dan pangan fungsional, kemudian dilanjutkan dengan pemeriksaan kadar gula darah, kolesterol, dan asam urat secara gratis yang dibantu oleh tenaga kesehatan dari Puskesmas terdekat, serta kader kesehatan desa.

\section{Penyuluhan terkait PTM dan Makanan Sehat}

Penyuluhan yang dilakukan dalam kegiatan pengabdian masyarakat ini yaitu penyuluhan mengenai hipertensi, T2DM, ganyong, spirulina, tepung Cannalina, IG, pangan, serta gizi dan kesehatan. Selain itu, dalam penyuluhan ini juga dilakukan pengenalan alternatif pangan dengan IG rendah kepada masyarakat, yaitu bubur, lontong, cookies yang terbuat dari tepung komposit ganyong dan spirulina (Cannalina).

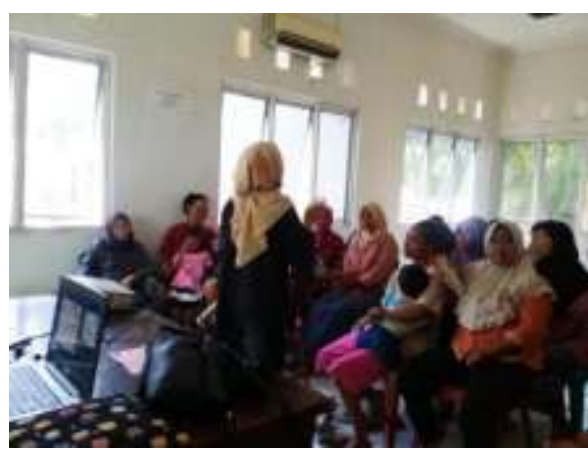

Gambar 1. Penyuluhan terkait PTM (penyebab dan cara menanganinya)

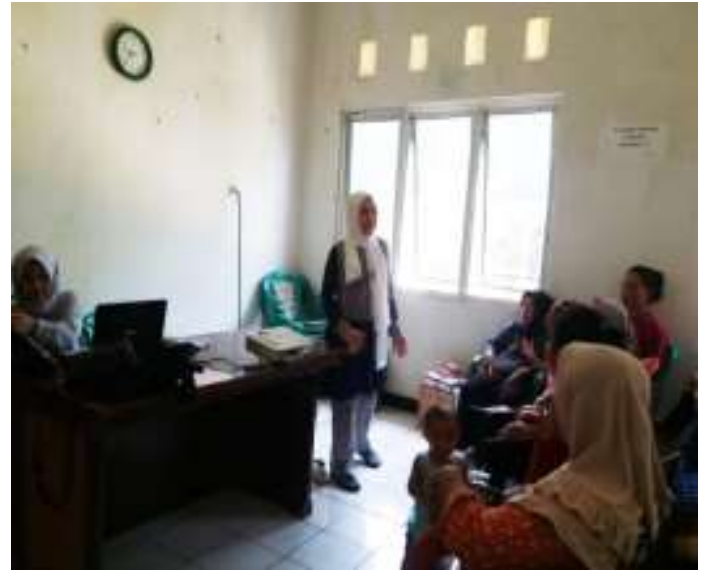

Gambar 2. Penyuluhan terkait Makanan Sehat (Cannalina)

Pemeriksaan status PTM Gratis, terdiri dari pemeriksaan: Kadar Gula Darah, Kolesterol, Asam Urat, dan Tekanan Darah

Pemeriksaan kadar gula darah, kolesterol, dan asam urat dilakukan dengan menggunakan Easy Touch GCU (Glucose, Cholesterol, and Uric acid). Pertama, blood lancet dimasukkan ke dalam lancing device, lalu tingkat kedalaman jarum diatur ke angka empat. Setelah itu, Easy Touch GCU dinyalakan dan strip glukosa dimasukkan ke dalamnya, sehingga akan muncul lambang darah di layar Easy Touch $G C U$. Kemudian, jari yang akan diambil darahnya dibersihkan terlebih dahulu menggunakan alcohol swab. Selanjutnya, lancing device didekatkan ke jari tersebut, lalu tombol yang terdapat pada lancing device ditekan. Darah yang pertama keluar diusap dengan alcohol swab. Lalu, jari ditekan perlahan dan darah yang keluar tersebut diletakkan pada strip glukosa yang telah terpasang pada Easy Touch GCU, sehingga akan muncul angka pada layar Easy Touch GCU. Angka tersebut menunjukkan kadar gula darah dengan satuan $\mathrm{mg} / \mathrm{dL}$.

Setelah itu, strip glukosa diganti dengan strip kolesterol. Kemudian, darah diletakkan pada strip kolesterol yang telah terpasang pada Easy Touch GCU, sehingga akan muncul angka pada layar Easy Touch GCU. Angka tersebut menunjukkan kadar kolesterol dengan satuan $\mathrm{mg} / \mathrm{dL}$. Selanjutnya, strip kolesterol diganti dengan strip asam urat. Kemudian, darah diletakkan kembali pada strip asam urat yang telah terpasang pada Easy Touch GCU, sehingga akan muncul angka pada layar Easy Touch $G C U$. Angka tersebut menunjukkan kadar asam urat dengan satuan $\mathrm{mg} / \mathrm{dL}$. 
Pemeriksaan tekanan darah dilakukan dengan menggunakan tensimeter digital. Pertama, manset tensi dililitkan pada tangan kiri di bagian lengan atas. Kemudian, tombol start ditekan, sehingga akan muncul angka pada indikator sistol dan diastol yang terdapat pada tensimeter digital. Angka tersebut menunjukkan tekanan darah dengan satuan $\mathrm{mmHg}$.

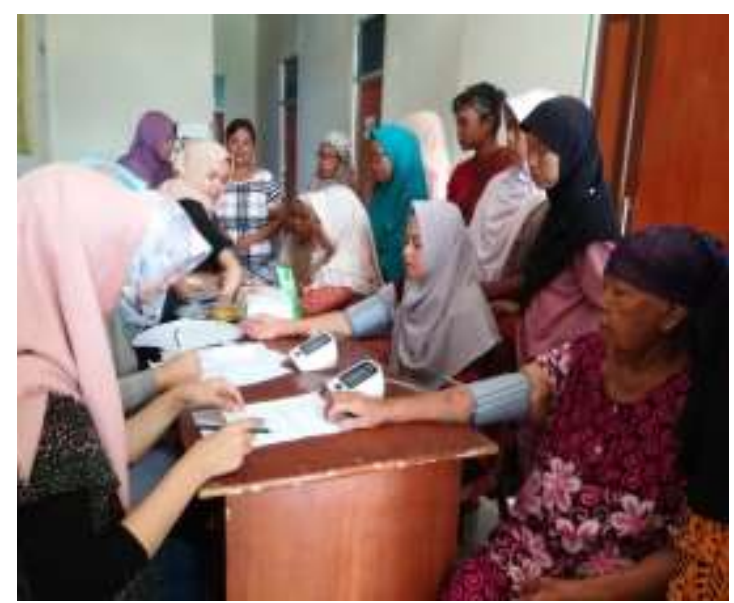

Gambar 3. Pemeriksaan status PTM gratis

\section{HASIL DAN PEMBAHASAN}

\section{Penyuluhan PTM dan Makanan Sehat}

Proses pengumpulan masyarakat dalam kegiatan ini dilakukan bersama-sama antara dosen dan mahahsiswa UAI, serta tenaga kesehatan dan kader kesehatan desa. Para kader kesehatan membantu menyebarkan informasi terkait kegiatan ini ke masyarakat desa. Kegiatan ini juga diliput oleh media setempat.

Total masyarakat yang hadir dan diberikan penyuluhan pada 6 April 2019 berjumlah 91 orang ibu rumah tangga yang terdiri atas 30 orang berusia 49 tahun ke atas dan 61 orang berusia di bawah 49 tahun sampai 19 tahun.

Masyarakat terlihat antusias terhadap penyampaian dari penyuluh yang ditandai dengan banyaknya pertanyaan yang berkaitan dengan kondisi kesehatan mereka saat ini. Hingga saat ini belum banyak informasi terkait PTM yang disampaikan kepada masyarakat di desa Dewisari.

Pekerjaan sehari - hari sebagian besar wanita berusia 49 tahun ke atas dan yang berusia 19 49 tahun yang mengikuti kegiatan ini adalah pekerjaan rumah tangga. Pekerjaan rumah tangga yang dilakukan umumnya adalah memasak, mencuci, dan merapikan rumah. Sebagian besar wanita yang terlibat memiliki pendapatan rumah tangga per bulan sekitar Rp 1.000.000 - 2.000.000.
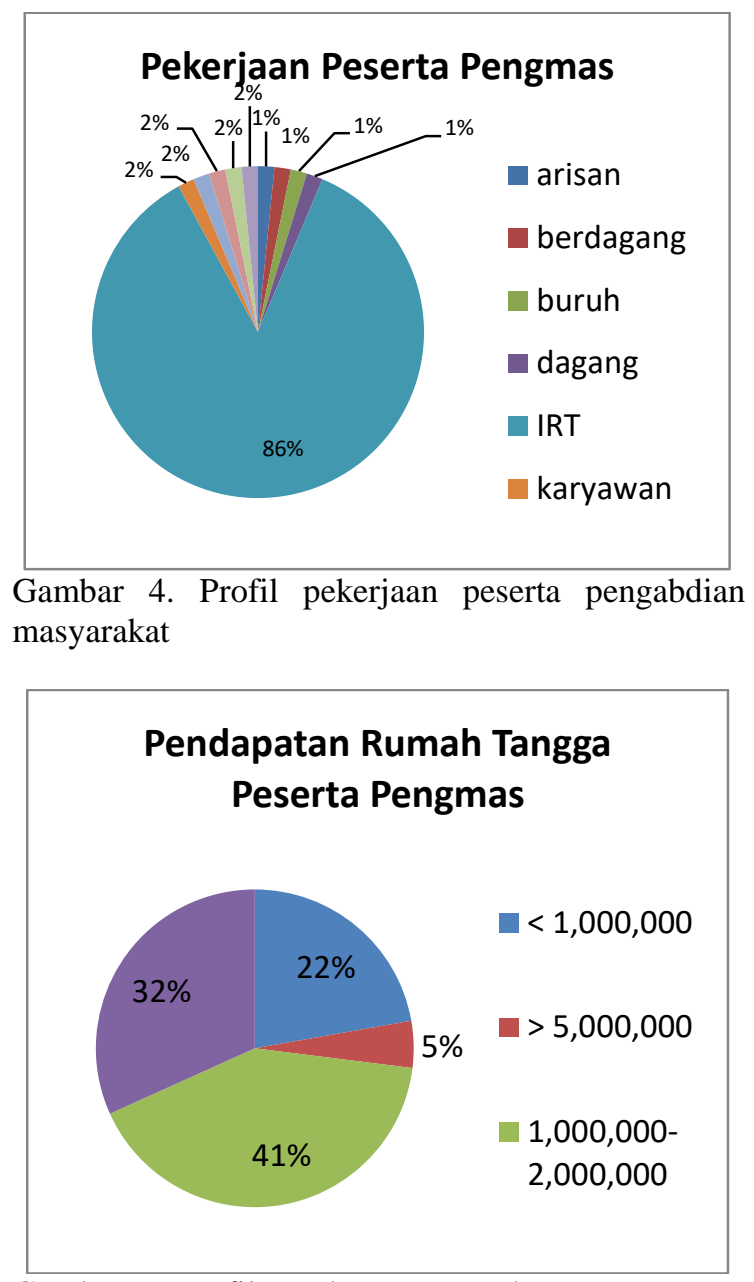

Gambar 5. Profil pendapatan rumah tangga peserta pengabdian masyarakat

Rincian materi konsultasi yang disampaikan adalah sebagai berikut:

a. Pedoman Gizi Seimbang

b. Perilaku Hidup Bersih dan Sehat (PHBS)

c. Penyakit Tidak Menular (PTM) dan pengobatan melalui pengaturan makanan

d. Pengaruh emosi dengan tekanan darah.

e. Sakit pada telapak kaki

f. Pengaruh konsumsi minuman instan terhadap kadar gula darahnya

g. Pengaruh konsumsi tahu dan tempe terhadap kadar asam urat darah

Pengabdian masyarakat berupa penyuluhan mengenai makanan sehat yang dilakukan adalah menanamkan pemahaman bahwa dalam sepiring menu makanan semakin berwarna semakin tinggi nilai gizinya seperti berikut ini dalam sepiring makanan terdapat: 
a. Nasi berwarna putih atau nasi merah

b. Telur berwarna kuning dan putih

c. Tempe berwarna coklat

d. Buncis berwarna hijau

e. Wortel berwarna oranye

f. Pentingnya variasi makanan pengganti nasi seperti olahan ganyong, singkong, ubi dan jagung, dan pentingnya makan buah-buahan.

\section{Pemeriksaan Status PTM Gratis}

Sebagian besar masyarakat antusias mendatangi kegiatan ini dikarenakan adanya pemeriksaan status kesehatan gratis yang jarang mereka dapatkan. Pengabdian masyarakat ini melakukan pemeriksaan kesehatan yang berkaitan dengan penyakit tidak menular (PTM) yaitu pemeriksaan tekanan darah, diabetes, kolesterol, dan asam urat.

Hasil pemeriksaan kondisi kesehatan ibu rumah tangga di atas usia 49 menunjukkan terdapat 21 orang tekanan darah tinggi yaitu di atas 120/80 mmHg, 4 orang gula darah sesaat lebih dari $200 \mathrm{mg} / \mathrm{dl}, 13$ orang kolesterol tinggi dan 10 asam urat tinggi. Proses pemeriksaan kesehatan juga diselingi oleh konsultasi singkat jika ibu rumah tangga menderita salah satu/lebih penyakit tidak menular berdasarkan hasil pemeriksaan. Konsultasi singkat yang disampaikan adalah berupa jenis makanan apa yang perlu ditingkatkan dan dihindari untuk menangani kondisi kesehatan yang ada.

Tabel 1. Profil kesehatan ibu rumah tangga di atas usia 49 tahun

\begin{tabular}{lc}
\hline Indikator kesehatan & $\mathbf{n}$ \\
\hline Tekanan darah tinggi & 21 \\
Diabetes berdasarkan GDS & 4 \\
Kolesterol tinggi & 13 \\
Asam urat tinggi & 10 \\
\hline
\end{tabular}

Kondisi kesehatan para ibu berusia 19 sampai 49 tahun adalah sebagai berikut :

a. 11 orang telah mengalami menopause dengan variasi usia 32, 39, 42, 43, 44 dan 45 tahun.

b. Aktif menggunakan KB 11 orang

c. Berdasarkan IMT 7 orang tergolong kurus, 20 orang gemuk dan 6 orang obesitas

d. Di atas batas normal untuk kadar gula 16 orang, kolesterol 7, Asam urat diatas normal 6 orang

e. 52 orang tidak mengetahui keluhan keluarga (orang tua, kakak dan adik)
Tabel 2. Profil kesehatan ibu rumah tangga usia 19 49 tahun

\begin{tabular}{lc}
\hline Indikator kesehatan & n \\
\hline Menopause & 11 \\
KB & 11 \\
Diabetes berdasarkan GDS & 16 \\
Kolesterol tinggi & 7 \\
Asam urat tinggi & 6 \\
\hline
\end{tabular}

\section{SIMPULAN DAN SARAN}

Kondisi kesehatan para ibu berusia 19 - 49 tahun menunjukkan dari 61 orang terdapat 11 orang sudah mengalami menopause. Kelainan metabolik seperti gula darah, kolesterol dan asam urat di atas normal serta gemuk dan obesitas. Hal ini adalah erat kaitannya dengan pola makan yang cenderung tinggi karbohidrat. Kondisi kesehatan para ibu yang berusia di atas 49 tahun berjumlah 30 orang menunjukkan tekanan darah, gula darah, kolesterol dan asam urat di atas normal.

\section{Saran}

Para ibu perlu diberikan pemahaman untuk mengontrol kesehatannya di Puskesmas paling tidak 2 bulan sekali. Hal ini merupakan langkah preventif agar penyakit cepat terdeteksi dan mudah ditanggulangi.

\section{DAFTAR PUSTAKA}

Badan Pusat Statistik Kabupaten Karawang. (2018). Kabupaten Karawang dalam Angka 2018. [Online]. Available: https://karawangkab.bps.go.id/publication/2 018/08/16/15536517a5343ea085261b3c/kab upaten-karawang-dalam-angka-2018.html. [Accessed: Nov. 1, 2019].

Fitriani, A. (2012). Kondisi Sosial Ekonomi dan Stres pada Wanita Hipertensi Anggota Majlis Taklim. Jurnal Kesehatan Masyarakat Nasional. 7 (5).

Kementerian Kesehatan. (2012). Masalah hipertensi di Indonesia. Kementeria Kesehatan Republik Indonesia.

Staruschenko, A. (2017). Hypertention and Diabetes mellitus. Hipertention. 69:787-788

Streppel, M., Arends, L., Veer, P. (2005). Dietary Fiber and Blood pressure A meta- 
analysis of Randomized Placebo Controlled trials. Arc. intern. Med. 165 (20), 150-156.

Sun, B., Shi, X., Wang, T., Zhang. (2018). Exploration of the Association between Dietary Fiber Intake and Hypertention among U.S. Adults Using 2017 American
College of Cardiology/ American Hearth Assosiation Blood Presure Guidelines : NHNES 2007-2014. Nutriens, 10(8): 1091. doi:10.3390/nu10081091. 